\title{
PACIENTŲ GRIUVIMO RIZIKĄ LEMIANTYS VEIKSNIAI
}

\author{
Lina Gedrimé $\dot{e}^{1,2,3,4}$, Jovita Dugaliené $\dot{e}^{2,4}$, Aelita Skarbaliené $\dot{e}^{3}$, Jelena Kutkauskiené $\dot{e}^{5}$, \\ Almeda Kuriené ${ }^{1}$, Natalja Fatkulina ${ }^{1}$ \\ ${ }^{I}$ Vilniaus universiteto Medicinos fakulteto Sveikatos moksly institutas, \\ ${ }^{2}$ Klaipeddos valstybine kolegija, ${ }^{3}$ Klaipèdos universiteto Sveikatos mokslu fakultetas, \\ ${ }^{4}$ Respublikinè Klaipèdos ligonine, ${ }^{5}$ Mykolo Romerio teisès mokyklos Viešosios teisès institutas
} \section{slauga.}

Raktažodžiai: pacientai, griuvimo rizika, veiksniai,

\section{Santrauka}

Pacientų sveikatos ir funkcinio savarankiškumo išsaugojimas keliamas kaip vienas pagrindinių uždavinių visam PSO Europos regionui. Svarbu užtikrinti pacientų geresnę sveikatą, gyvenimo kokybę ir vertinti fiziologinius pokyčius senstant. Gera pusiausvyra ir mobilumas yra pagrindinès sèkmingo kasdienio gyvenimo bei mègstamos veiklos prielaidos. Pacientu griuvimas yra aktuali problema, tačiau Lietuvoje nèra plačiai nagrinejjama. Pacientai traumas patiria ne tik namuose, gatveje, bet ir gydymo ịstaigoje. Tyrimo tikslas - išanalizuoti pacientu žinias apie griuvimo rizikos veiksnius.

Tyrimas vykdytas $2020 \mathrm{~m}$. lapkričio-gruodžio mèn. anketinès apklausos būdu. Apklausoje dalyvavo 104 asmenys nuo 55 metų, turintys judejimo, kraujotakos, jutimų, pusiausvyros sutrikimų ar kitų gretutinių ligų, galẻjusių turèti įtakos griuvimams. Klausimynas sudarytas iš 5 dalių, atspindinčių konkrečius klausimus, pateikiamas kiekvienos tyrimo dalies aprašymas.

Dauguma tiriamųjų buvo pargriuvę ir jaute galvos svaigimą. Nors respondentai jautesi stabiliai judedami (jaučia, kad gali paeiti tiesia linija), tačiau baimé pargriūti ribojo jų fizinị aktyvumą, jie reguliariai nesimankštino. Dauguma tiriamųu ų pargriuvę patyrè sumušimus. Respondentų nuomone, dažniausiai griuvimus gali sukelti tokie išoriniai veiksniai kaip slidžios grindys, netinkama avalynė, prastas apšvietimas ar turèklų nebuvimas. Galimi ir vidiniai veiksniai - galvos svaigimas, raibuliavimas akyse. Pacientai yra suinteresuoti ir nori sužinoti, kaip pagerinti pusiausvyrą.

\section{Ivadas}

Senstant blogèja pusiausvyra ir prastėja gebèjimas išlaikyti kūno padètị erdvèje, sutrinka sensorinès sistemos funkcijos, mažèja raumenų apimtis ir masè, raumenų skaidulų skaičius, keičiasi laikysena, mažèja pusiausvyros kontrolè. Norint išlaikyti pusiausvyrą, reikia aštraus regejimo, somatosensorinių vestibulinių funkcijų dalyvavimo ir prisitaikymo prie kintančių sąlygų. Pagyvenusiems žmonèms sutrinka vestibulinė sistema, ivvyksta regos sistemų pokyčiai ir šios funkcijos gerokai pablogèja. Kai sutrinka informacijos perdavimas iš regimosios ir vestibulinès sistemų, informacija nebesiunčiama ị centrinę nervų sistemą, galimas pusiausvyros sutrikimas [1]. Senstant vyksta sensomotorinès ir vestibulinès sistemos pokyčiai, turintys didelę itaką griuvimui [2]. Griuvimus patiria ne tik senyvo amžiaus žmonès, tačiau senyvo amžiaus žmonėms griuvimo pasekmès yra sunkesnès ir riboja jų mobilumą bei kasdienę veiklą [3]. Griuvimas labai prisideda prie senejjančios visuomenès mirtingumo, sergamumo ir išlaidų [4].

Griuvimo sukelti sužalojimai yra didžiausia pagyvenusių žmonių atsitiktinès mirties priežastis visoje Europoje. Griuvimas susijęs su sumažejjusiu funkcionavimu, psichologinėmis problemomis, tokiomis kaip baimé griūti ir pasitikejjimo praradimas, sukeliančiomis socialinę izoliaciją ir padidejusią priklausomybę nuo aplinkinių [5].

Griuvimas dažniausiai turi medicinines pasekmes, net iki 60 proc. pacientu griuvimas baigiasi nesėkmingai, kaip padarinys nustatomos minkštujų audinių ir judamojo - atramos aparato traumos. Labai svarbus autonomijos ir mobilumo išsaugojimas pagyvenusiame amžiuje, bei griuvimo rizikos veiksnių îvertinimas. Normalus judèjimas, pusiausvyros kontrolè atliekant įvairius kasdienius veiksmus turi glaudžias sąsajas su sveikata ir siejasi su įvairiais veiksniais, ypač amžiumi [6].

Senyvo amžiaus žmonių sveikatos ir savarankiškumo išsaugojimas yra vienas pagrindinių uždavinių visam PSO Europos regionui. Fiziologiniai senejjimo pokyčiai, tokie kaip suvokimo, sąnarių judesių amplitudès sutrikimai, raumenų jëgos sumažejimas, suvokimo, ar reakcijos laiko suletėjimas, sensorinès sistemos pokyčiai daro ịtaką pusiausvyrai ir sukelia pusiausvyros kontroless sutrikimus. Gera pusiausvyra ir 
mobilumas suteikia galimybę džiaugtis kasdieniu gyvenimu bei mėgstama veikla. Kasmet gydytojo pagalbos dẻl rimtu sužalojimų ir kritimo prireikia 37,3 milijono žmonių. Lietuvoje mirtingumas nuo kritimų 100000 gyventojų padidejo nuo 9,8 (2010 m.) iki 12,0 (2014 m.) ir pralenkè daug metu pirmavusią išorinių mirties priežasčių kategoriją - eismo įvykius [7].

PSO atliko tyrimus ir griuvimų rizikos veiksnius suskirstė i keturias pagrindines grupes: 1) biologiniai rizikos veiksniai (amžius, lètinès ligos); 2) elgsesio rizikos veiksniai (vaistų vartojimas, nepakankamas fizinis aktyvumas); 3) aplinkos rizikos veiksniai (slidžios grindų dangos, laiptai, netinkamas apšvietimas, netinkamos lovos); 4) socialiniai rizikos veiksniai (bendravimo stoka). Griuvimo rizikos veiksniai skirstomi ị vidinius ir išorinius: vidiniai rizikos veiksniai yra glaudžiai susiję su medžiagų apykaita, judejimo ir atramos sistema, su rega, klausa, vaistų vartojimu, žmogaus elgesiu. Išoriniai rizikos veiksniai siejami su nesaugia aplinka, netinkama apranga, pagalbinių priemonių stoka [8].

Tyrimo tikslas - išanalizuoti pacientų žinias apie griuvimo rizikos veiksnius.

\section{Tyrimo medžiaga ir metodai}

Tyrimo objektas - pacientu griuvimo riziką lemiantys veiksniai. Tyrime dalyvavo 104 respondentai, kurie atitiko tyrimo dalyvavime nustatytus reikalavimus. Imtis - paprastoji atsitiktinè, t.y. visi respondentai nuo 55 metų, turintys judèjimo, kraujotakos, jutimų, pusiausvyros sutrikimų ar kitų gretutinių ligų, galëjusių turèti įtakos griuvimui.

Duomenų rinkimo metodai: uždaro tipo klausimynas, naudotas sužinoti ir išanalizuoti respondentų žinias apie griuvimo rizikos veiksnius. Klausimyną sudare 16 uždaro tipo klausimų. Klausimynas sukurtas analizuojant mokslinius šaltinius. Pasirinktas kiekybinis tyrimo metodas - apklausa. Klausimynas sudarytas iš 5 dalių, atspindinčių konkrečius

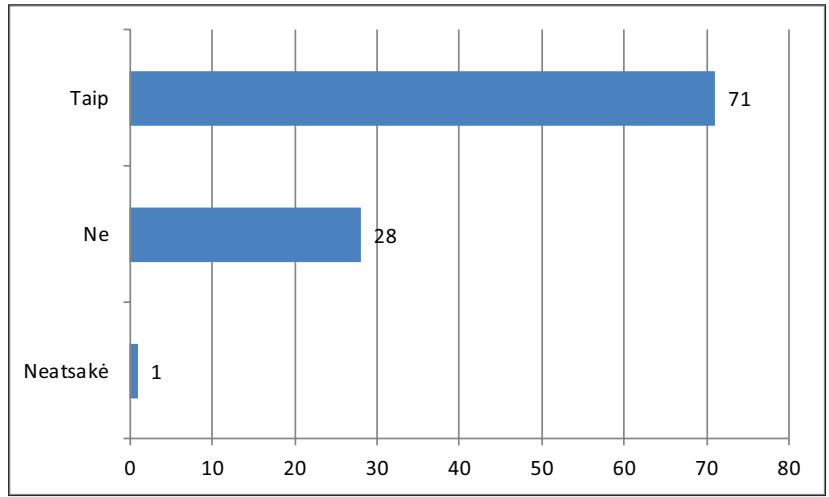

1 pav. Tiriamųjų fizinio aktyvumo ribojimo dèl baimès pargriūti dažnis, proc. klausimus, pateikiamas kiekvienos klausimyno tyrimo dalies aprašymas.

Dèl Covid 19 pandemijos nebuvo galima pateikti klausimyno raštu gydymo įstaigose, todèl klausimynas buvo patalpintas internetinejje svetainejje Apklausa.lt. Apklausa viešinta socialiniame tinkle „Facebook“ slaugytojų ir senjorų grupėse: „Lietuvos slaugytojų grupe““, „Vienišų senjorų grupe““, „Kam per 60“. Susisiekus su šių grupių administratoriais buvo užtikrinta, kad grupems priklauso pagyvenusio amžiaus žmonès. İ pateiktus klausimus tyrimo dalyviai atsakè gavę nuorodą į klausimyną.

Duomenu analizès metodai. Statistinei tyrimo duomenų analizei atlikti buvo naudojama Microsoft Office Excel skaičiuoklès programinè ịranga. Apklaustų tiriamujjų klausimyno duomenys pateikti stulpelinèse diagramose ir lentelèse. Duomenys pateikiami procentine išraiška.

\section{Tyrimo rezultatai}

Tiriamieji atsakè ị demografinius klausimus apie pacientų lytị ir amžių. Tyrime dalyvavo didesnè dalis moterų (63 proc.) nei vyru (37 proc.). Dauguma (43 proc.) apklaustujų buvo 55-60 metų, vyresnių nei $71 \mathrm{~m}$. respondentų buvo mažuma. $76-80 \mathrm{~m}$. respondentai sudare 6 proc. visų tiriamujų, $81-85 \mathrm{~m} .-8$ proc. tiriamujų, $86-90 \mathrm{~m} .-1$ proc. tiriamuјu, o daugiau nei $91 \mathrm{~m} .-4$ proc. tiriamujų.

Tirta, ar respondentai yra patyrę griuvimą, ar turi pusiausvyros sutrikimų ir ar šie veiksniau turi ịtakos tiriamųjų fiziniam aktyvumui. Tyrimo metu išryškèjo, kad net 61 proc. tyrime dalyvausių asmenų buvo pargriuvę per praejjusius 12 mènesių. Pargriuvusių asmenų skaičius rodo, kad senyvo amžiaus asmenų griuvimui reikia skirti daug dèmesio.

Tiriant išryškèjo, kad net 30 proc. respondentų anksčiau nèra praradę pusiausvyros, tačiau nemaža dalis (19 proc.) jų teigè, kad pusiausvyrą praranda 1-2 kartus per savaitę, 9 proc. $-3-4$ kartus per savaitę, 10 proc. $-1-2$ kartus per

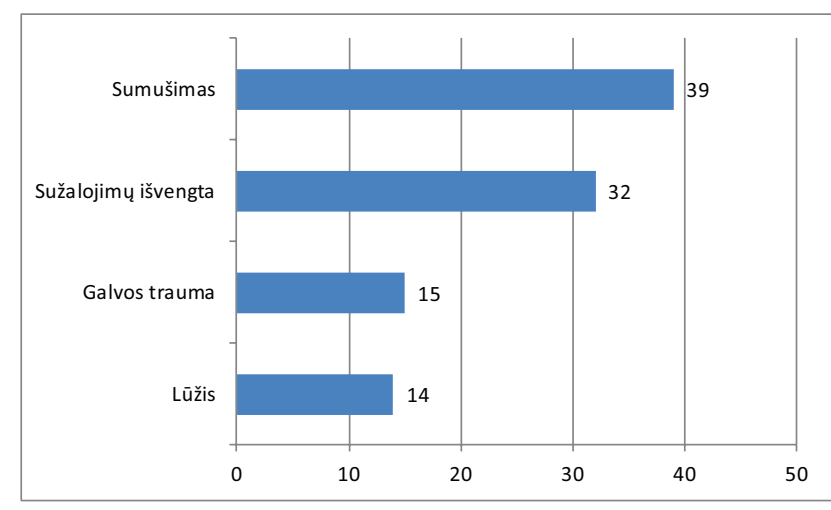

2 pav. Tiriamųjų patirtų griuvimo traumų dažnis, proc. 
ménesí, 6 proc. - 3-4 kartus per mėnesị. Kiekvieną dieną prarandantys pusiausvyrą teige tik 5 proc. tyrimo dalyvavių. Nepaisant to, galima teigti, kad nemaža dalis apklaustujų pusiausvyrą praranda gana dažnai.

Mokslininkų tyrimai rodo, kad baimę pargriūti jaučia 2050 proc. vyresnio amžiaus žmonių ir tai gali būti racionalus psichologinis atsakas $i$ ankstesnius kritimus. Nustatyta, kad kritimo baimè pasireiškia nuo 12 iki 65 proc. asmenų, kurie nebuvo pargriuvę ir nuo 29 iki 92 proc. asmenų, kurie yra patyrę kritimo baimę (nepasitikèjimas palaikant pusiausvyrą iprastinès veiklos metu). Kritimo baimę jaučia daugelis vyresnio amžiaus žmonių, neatsižvelgiant ị tai, ar jiems yra tekę pargriūti $[9,10,11]$.

Domètasi, ar baimè pargriūti riboja respondentų fizinị aktyvumą. Net 71 proc. tiriamujjų teigè, kad baimè riboja jų mobilumą (1 pav). Nors griuvimo baimé riboja apklaustujjų fizini aktyvumą, mokslininkai akcentuoja, kad reikia skatinti fizinę veiklą, kuri ne tik stiprina raumenis, bet ir gerina pusiausvyrą ir gali sumažinti griuvimo riziką $[12,13]$.

Galvos svaigimas yra pagrindinis kritimo veiksnys arba vienas iš pagrindinių veiksnių, didinančių kritimo riziką, todèl svarbu buvo įvertinti, ar tiriamieji patiria galvos svaigimą $[11,14]$.

Didelè dalis respondentų nurodè, kad jie patiria galvos svaigimą. Galima teigti, kad būtent galvos svaigimas galèjo sukelti ir šioje apklausoje dalyvavusių respondentų griuvimą.

Griuvimas didina griuvimo baimę, gali sukelti ịvairių komplikacijų ir traumų. Mokslininkai akcentuoja, kad apie 20 proc. vyresnio amžiaus žmonių po griuvimo reikia medicininès pagalbos: 15 proc. patiria sąnarių išnirimus, minkštụjų audinių mèlynes ir sumušimus, 5 proc. - lūžius, 1-2 proc. - šlaunikaulio kaklo lūžius [9]. Šiame tyrime, apklausus pacientus, nustatyta, kad net 39 proc. respondentuc griūdami patyre sumušimus, 32 proc. sužalojimų išvengé,

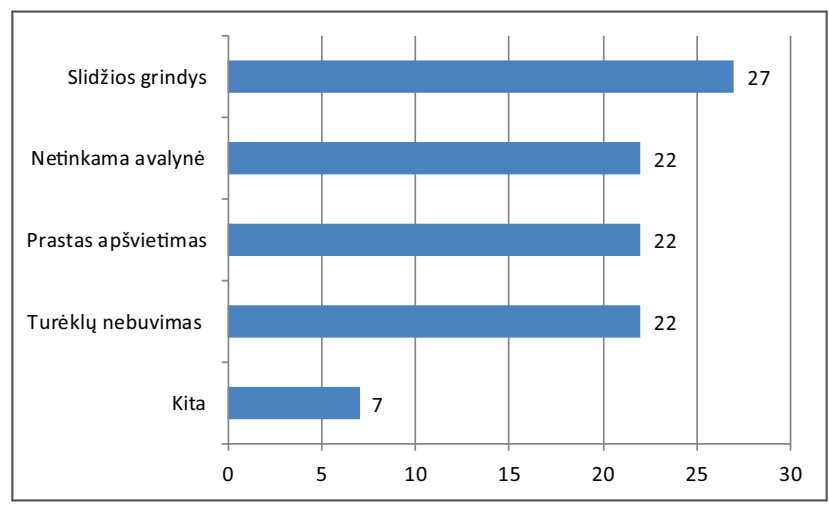

3 pav. Tiriamųjų nuomonès apie pagrindines išorines griuvimo priežastis dažnis, proc. tačiau buvo ir tokių, kurie pargriuvę patyrẻ kaulų lūžius (14 proc.) bei galvos traumas (15 proc.) (2 pav.).

Pasak V. Janušonio [15], pagrindinès veiksmingos griuvimų prevencijos priemonès yra senyvo amžiaus pacientų mokymas ir informavimas. Tai patvirtino ir atlikto tyrimo duomenys. Net 85 proc. tyrime dalyvavusių respondentu yra suinteresuoti ir nori sužinoti, kaip pagerinti pusiausvyrą.

Rizikos veiksnius galima suskirstyti ị dvi pagrindines grupes, kurios laikomos svarbiomis, nustatant kritimo priežastis: vidinès ir išorinès [16]. Esminiai veiksniai laikomi tiesiogiai susijusiais su paciento fizine ir psichologine situacija, pavyzdžiui, raumenų ir kaulu sistemos sutrikimai, vaistų vartojimas. Išoriniais veiksniais laikomi visi veiksniai, tiesiogiai ar netiesiogiai susiję su paciento kontekstu, pvz., netinkamas apšvietimas, kliūčiu buvimas, turèklų ir vonios laikiklių nebuvimas bei kiti [17]. Mokslininkai mini išorines ir vidines priežastis. Dažniausi išoriniai griuvimo rizikos veiksniai: slidūs grindų paviršiai palatose, duše, tualete ar vonioje, laikiklių vonioje nebuvimas, aukštai pakabintos lentynos, nepakankamas apšvietimas, neturintys turéklų

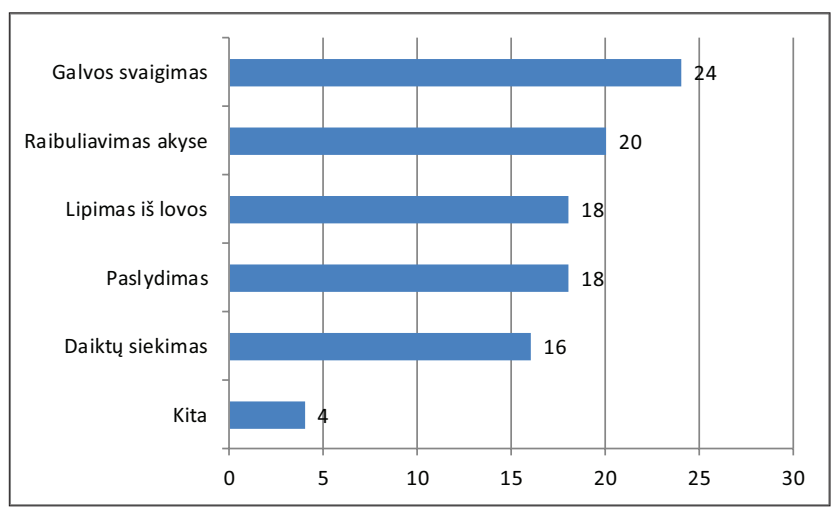

4 pav. Tiriamųjų nuomonès apie vidines griuvimo priežastis dažnis, proc.

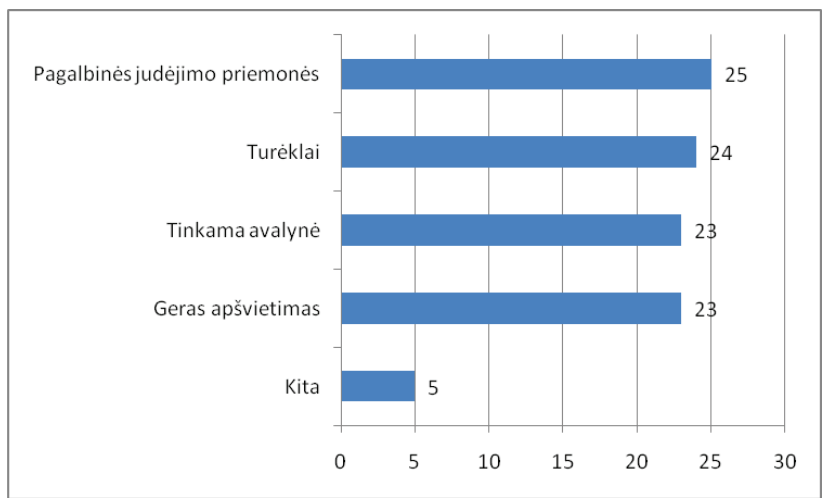

5 pav. Tiriamujų nuomonès apie galimas griuvimo prevencijos priemones dažnis, proc. 
laiptai, kilimèliai ir takeliai, nepritvirtinti prie vaikščiojamojo paviršiaus, netinkama avalynė [18]. Atliekant tyrimą domètasi, kokias išorines griuvimų priežastis tiriamieji žino. Nustatyta, kad pagrindinė griuvimo priežastis yra slidžios grindys (27 proc.). Respondentai teigè, kad griuvimą gali sukelti netinkama avalyne ( 22 proc.), prastas apšvietimas (22 proc.) ar turèklų nebuvimas (22 proc.) (3 pav.).

Prie vidinių griuvimo priežasčių galima priskirti ir regèjimo problemas bei galvos svaigimą, kuris gali sunkinti saugų judejjimą. Pagrindine vidine griuvimo priežastimi apklaustieji laiko galvos svaigimą - su tuo buvo linkę sutikti 24 proc. tiriamujų (4 pav.).

Respondentai nurodè, kad griuvimą gali sukelti raibuliavimas akyse (20 proc.), slydimas (18 proc.), lipimas iš lovos (18 proc.), daiktų siekimas (16 proc).

Tyrimo metu siekta išsiaiškinti respondentų žinias apie griuvimų prevencines priemones.Nustatyta, kad dauguma tiriamuju jomis laiko - pagalbines judèjimo priemones ( 25 proc.), dalis respondentų taip pat sutinka, kad griuvimų gali padèti išvengti ir turèklai (24 proc.), tinkama avalynė (23 proc.) ar geras apšvietimas (23 proc.) (5 pav.).

Pagalbinių judèjimo priemonių svarbą, siekiant sumažinti griuvimo atvejus, aprašè T. Peach ir kt. [19]. Mokslininkų atlikto tyrimo duomenimis, viena iš pagrindinių pagalbinių priemonių pacientams yra lazda, kuri teikia jiems pasitikèjimo savimi, ramina ir teikia saugumo jausmą.

\section{Išvados}

1. Atliktas tyrimas patvirtino PSO tyrimų rezultatus, kad griuvimo rizikos veiksnius galima suskirstyti ị biologinius, elgesio, aplinkos ir socialinius. Biologinis rizikos veiksnys yra amžius (tikimybe patirti griuvimus didejja nuo $55 \mathrm{~m}$. ir daugiau); elgesio rizikos veiksniai yra vaistų vartojimas (antidepresantai, antihipertenziniai, migdomieji, raminamieji stipriai didina griuvimo riziką) ir nepakankamas fizinis aktyvumas; aplinkos rizikos veiksniais laikomos slidžios grindų dangos, laiptai, netinkamas apšvietimas, netinkamos lovos; socialinis rizikos veiksnys yra bendravimo stoka (labai svarbus slaugytojo vaidmuo ir informacijos suteikimas pacientui).

2. Pusiausvyros vertinimas, vestibuliariniai pratimai, D vitamino vartojimas, komforto kontrolè, fizinis aktyvumas, lètinėmis ligomis sergančiu žmonių stebèjimas, slaugytojų bendravimas su pacientais, geresnis jų poreikių žinojimas yra pagrindinès prevencinès priemonès stacionare. Ne mažiau svarbus yra saugios aplinkos kūrimas pacientu gyvenamojoje aplinkoje: pagalbinių priemonių pritaikymas, slankiojančių ar nepritvirtintų kilimėlių pašalinimas, neslidžių grindų palatose, duše, tualete ar vonioje dejjimas, laikiklių voniose irengimas.

\section{Literatūra}

1. Rutkauskienė L, Piščalkienė V, Gintilienė M, Zachovajevienė B, Kavaliauskienė A, Vyresnio amžiaus asmenų pusiausvyros vertinimas naudojant „Saigma Balance Pad“. Visuomenès sveikata, 2012;5:52-56.

https://doi.org/10.5200/sm-hs.2012.097

2. Strukčinskaitė V., Norkienė S., Strukčinskienė B. Pagyvenusių žmonių kritimai: rizikos veiksniai ir prevencijos galimybès. Visuomenès sveikata, 2016;26(6):102-108.

https://doi.org/10.5200/sm-hs.2016.099

3. Teixeira K, Andrade M, Santos P, Caires S. Falls among the elderly: environmental limitations and functional losses. Revista Brasileira de Geriatria e Gerontologia 2019;22(3). https://oi.org/10.1590/1981-22562019022.180229

4. Marschollek M, Rehwald A, Wolf H, Gietzelt M, Nemitz G., Meyer zu Schwabedissen H, Haux R. Sensor-based fall risk assessment - an expert "to go." Methods of Information in Medicine 2011; 50(5), 420-426.

https://doi.org/10.3414/ME10-01-0040

5. Stanmore K, Mavroeidi A, de Jong D, Skelton D, Sutton C, Benedetto V, Munford L, Meekes W, Bell V, Todd C. The effectiveness and cost-effectiveness of strength and balance Exergames to reduce falls risk for people aged 55 years and older in UK assisted living facilities: a multi-centre, cluster randomised controlled trial. BMC Med. 2019;17(1):49.

https://doi.org/10.1186/s12916-019-1278-9

6. Janušonis V. Pacientų griuvimai ligoninèje - nepageidautini, tačiau neišvengiami ịvykiai: 15 metų patirties analizè. Visuomenès sveikata, 2015;25(6):44-50.

https://doi.org/10.5200/sm-hs.2015.115

7. Strukčinskaitė V., Norkienė S., Strukčinskienė B. Pagyvenusių žmonių kritimai: rizikos veiksniai ir prevencijos galimybès. Visuomenès sveikata, 2016;26(6):102-108.

https://doi.org/10.5200/sm-hs.2016.099

8. Kubiliūtė K. Dažnai griūvančių senų žmonių reabilitacijos ypatumai. Gerontologija, 2014;15(3): 193-199.

9. Rutkauskienė L., Piščalkienė V., Gintilienė M., Zachovajevienė B., Kavaliauskienė A. Vyresnio amžiaus asmenų pusiausvyros vertinimas naudojant "Saigma Balance Pad". Visuomenès sveikata, 2012;5:52-56.

https://doi.org/10.5200/sm-hs.2012.097

10. Mendes da Costa E, Pepersack T, Godin I, Bantuelle M, Petit B, Leveque A. Fear of falling and associated activity restriction in older people. results of a cross-sectional study conducted in a Belgian town. Arch Pub Health 2012;70:1-10.

https://doi.org/10.1186/0778-7367-70-1

11. Jefferis BJ, Iliffe S, Kendrick D. How are falls and fear of falling associated with objectively measured physical activity in a cohort of community-dwelling older men? BMC Geriatr 2014;14(114).

https://doi.org/10.1186/1471-2318-14-114 
12. Borges M, Moreira K, The influences of the physical activity practice on aging: a comparative study on the autonomy level for performance on DLAs and IADLs between the physically active and sedentary elderly. Motriz 2009;15(3):562-573.

13. Jefferis J, Iliffe S, Kendrick D, et al. How are falls and fear of falling associated with objectively measured physical activity in a cohort of community-dwelling older men? 2014;14:1-9 https://doi.org/10.1186/1471-2318-14-114

14. Ciorba A. Dizziness and the risk of falling in the elderly: a literature review. J Hear Sci 2015;5(1):9-13.

15. Janušonis V., Vaitiekienė J. Nepageidautini įvykiai sveikatos priežiūroje: pacientų griuvimų ligoninèse patirtis. Sveikatos mokslai, 2013;23(3):5-11. https://doi.org/10.5200/sm-hs.2013.065

16. Deandrea S, Lucenteforte E, Bravi F, Foschi R, La Vecchia C, Negri E. Risk factors for falls in community-dwelling older people: a systematic review and meta-analysis. Epidemiology 2010:658-68.

https://doi.org/10.1097/EDE.0b013e3181e89905

17. Corrales CE, Bhattacharyya N. Dizziness and death: an imbalance in mortality. Laryngoscope 2016;126:2134-6. https://doi.org/10.1002/lary.25902

18. Figueiro MG, Plitnick B, Rea MS, Gras LZ, Rea MS. Lighting and perceptual cues: effects on gait measures of older adults at high and low risk for falls. BMC Geriatr 2011;11:49. https://doi.org/10.1186/1471-2318-11-49

19. Peach T, Pollock K, van der Wardt V, das Nair R, Logan P, Harwood RH. Attitudes of older people with mild dementia and mild cognitive impairment and their relatives about falls risk and prevention: a qualitative study. PLoS One 2017;12(5):e0177530.

https://doi.org/10.1371/journal.pone.0177530

\section{FACTORS INFLUENCING THE RISK OF PATIENTS FALL}

L. Gedrimè, J. Dugalienė, A. Skarbalienė, J. Kutkauskienė, A. Kurienè, N. Fatkulina

Keywords: Patients, risk of fall, determinants. Summary

Research problem. Preserving patients' health and maintaining functional independence is one of the main challenges for the whole European region. It is important to ensure better health, qu- ality of life for patients, and to assess physiological changes as they age. Good balance and mobility are the main prerequisites for a successful daily life and favorite activity (Strukčinskaitè et al. 2016). However, the problem is not widely discussed, published, and patients experience injuries not only at home, on the street, but also in the treatment facility. So the question is, what are the causes of patient falls? How can a safe environment for patients be ensured?

Reseach object. Risk factors for patient fall.

The aim: To analyze the factors determining the risk of patients falling.

Research methods. Scientific literature analysis: quantitative research; online survey.

Results. Most of the patients this year had fallen and were feeling dizzy. Although patients felt stable in movement (felt that they could walk in a straight line), the fear of falling limited the patients "physical activity, they did not exercise regularly. The majority of patients experienced bruises after the fall, and the majority of patients diagnosed with diabetes were diagnosed by disease. According to the patients interviewed, falls are most often caused by external factors such as slippery floors, unsuitable footwear, poor lighting or the absence of handrails. Internal are dizziness, flutter in the eyes. Patients are interested and eager to learn how they can improve their balance.

Conclusions. Physiological changes in aging, such as disturbances in perception, joint amplitude, decreased muscle strength, slowing in perception or response time, and changes in the sensory system, affect balance and cause balance control. Risk of fall factors are divided into internal and external: internal risk factors are closely related to metabolism, vision, hearing, medication use, human behavior. External risk factors are associated with an unsafe environment, inappropriate clothing, lack of support measures, and their inadequacy for the everyone patient. Balance assessment, vestibular exercises, vitamin D intake, comfort control, physical activity, monitoring of people with chronic diseases, communication between nurses and patients, better knowledge of their needs are the main preventive measures in the hospital. Equally important is the creation of a safe environment in the living environment of patients: the application of aids, the removal of sliding or loose mats, the avoidance of slippery floor surfaces in wards, showers, toilets or baths.

Correspondence to: linagedrimaite@gmail.com

Gauta 2021-03-17 